\title{
PERBEDAAN EFEKTIVITAS PENGGUNAAN OBAT ANTIDIABETIK ORAL TUNGGAL DENGAN KOMBINASI PADA PASIEN DM TIPE 2 DI UPT. PUSKESMAS DAWAN II KABUPATEN KLUNGKUNG PERIODE NOVEMBER 2015-PEBRUARI 2016
}

\author{
(DIFFERENCES IN THE EFFECTIVENESS ORAL ANTIDIABETICS SINGLE USE WITH \\ COMBINATION OF TYPE 2 DM PATIENTS IN UPT. DAWAN II PUBLIC HEALTH DISTRICT \\ KLUNGKUNG IN NOPEMBER 2015-PEBRUARI 2016)
}

\author{
NI NYOMAN WAHYU UDAYANI ${ }^{\bullet} \cdot$ HERLEEYANA MERIYANI $^{1}$ \\ ${ }^{1}$ Akademi Farmasi Saraswati Denpasar, Jalan Kamboja No.11A, Denpasar, Bali
}

\begin{abstract}
Abstrak: DM tipe 2 merupakan penyakit progresif dengan karakteristik penurunan fungsi sel beta pankreas. Penelitian ini bertujuan untuk mengetahui perbedaan efektivitas penggunaan obat antidiabetik oral tunggal dengan kombinasi pada pasien DM tipe 2 di UPT. Puskesmas Dawan II Kabupaten Klungkung. Penelitian ini merupakan penelitian cross sectional dan pengumpulan data dilakukan secara prospektif. Penelitian dilakukan dari bulan November 2015-Pebruari 2016 di UPT. Puskesmas Dawan II Kabupaten Klungkung. Penelitian dilakukan terhadap 25 subjek penelitian dengan terapi tunggal glibenklamid dan 25 subjek penelitian dengan terapi kombinasi glibenklamid dengan metformin. Hasilnya menunjukkan bahwa tidak terdapat perbedaan bermakna dari efektivitas penggunaan obat antidiabetik oral tunggal glibenklamid dengan kombinasi glibenklamid dengan metformin pada pasien DM tipe 2 di UPT. Puskesmas Dawan II Kabupaten Klungkung periode November 2015-Pebruari 2016 ( $\mathrm{p}=0.114$ ).
\end{abstract}

Kata kunci: antidiabetik oral kombinasi, antidiabetik oral tunggal, diabetes melitus tipe 2

\begin{abstract}
Type 2 diabetes is a progressive disease with characteristics of pancreatic beta cell function decline. This study aims to determine differences in the effectiveness of the use of a single oral antidiabetic drugs and combinations in patients with type 2 diabetes in UPT. Health Center II Dawan Klungkung regency. This study is cross- sectional and prospective data collection is done. The study was conducted from November 2015 to February in 2016 in UPT. Health Center II Dawan Klungkung regency. Research carried out on 25 research subjects with glibenclamide monotherapy and 25 research subjects with combination therapy with metformin glibenclamide. The results show that there is no significant difference on the effectiveness of the use of a single oral antidiabetic drug glibenclamide and glibenclamide combination with metformin in patients with type 2 diabetes in UPT. Health Center II Dawan Klungkung regency period November 2015 - February 2016 ( $\mathrm{p}=$ $0.114)$.
\end{abstract}

Keywords: combination oral antidiabetic, diabetes mellitus type 2, single oral antidiabetic.

\section{PENDAHULUAN}

Diabetes Melitus (DM) merupakan suatu kelompok penyakit metabolik dengan karakteristik hiperglikemia yang terjadi karena kelainan sekresi insulin, gangguan kerja insulin atau kedua-duanya yang menimbulkan berbagai komplikasi kronik pada mata, ginjal, saraf dan pembuluh darah (American Diabetes Association, 2012). International Diabetes Federation (IDF) menyebutkan pada tahun 2012 angka kejadian diabetes melitus di dunia adalah sebanyak 371 juta jiwa, dimana proporsi kejadian diabetes melitus tipe 2 adalah $95 \%$ dari populasi dunia yang menderita diabetes melitus.
Diabetes melitus tipe 2 umumnya terjadi karena kombinasi dari resistensi insulin dan berkurangnya sekresi insulin akibat menurunnya fungsi sel beta pankreas (Tjay dan Rahardja, 2007). Diabetes melitus tipe 2 disebut dengan the silent killer karena penyakit ini dapat mengenai semua organ tubuh dan menimbulkan berbagai macam keluhan. Diabetes melitus tipe 2 merupakan penyakit progresif dengan komplikasi akut maupun kronik. Dengan penatalaksanaan yang baik, angka morbiditas dan mortalitas dapat diturunkan. Untuk menurunkan kejadian dan keparahan dari Diabetes melitus tipe 2 maka dilakukan pencegahan seperti modifikasi gaya hidup dan pengobatan secara farmakologi seperti obat antidiabetik oral dan suntikan (Arifin, 2011).

\footnotetext{
• email korespondensi: udayani.wahyu@yahoo.com
} 
Pengobatan secara farmakologi diberikan apabila kadar glukosa darah belum mencapai sasaran hanya dengan modifikasi gaya hidup. Terapi antidiabetik oral merupakan terapi farmakologi utama untuk mengatasi diabetes melitus tipe 2. Terapi dapat berupa terapi antidiabetik tunggal maupun kombinasi dua antidiabetik oral. Terapi antidiabetik oral diberikan untuk penderita yang memiliki kadar gula darah puasa $>126 \mathrm{mg} / \mathrm{dL}$ (PERKENI, 2011).

Terapi antidiabetik oral yang dapat diberikan untuk penderita DM tipe 2 seperti golongan sulfonilurea seperti glibenklamid yang memiliki cara kerja meningkatkan sekresi insulin oleh sel beta pankreas dan golongan penghambat glukoneogenesis seperti metformin yang memiliki cara kerja mengurangi produksi glukosa hati (glukoneogenesis) atau terapi kombinasi dari golongan sulfonilurea dengan golongan penghambat glukoneogenesis (PERKENI, 2011).

Pada UPT. Puskesmas Dawan II Kabupaten Klungkung angka penderita Diabetes Melitus tipe 2 merupakan penyakit kronik yang memiliki kedudukan tertinggi dari 10 besar penyakit yang ada dan penderitanya selalu bertambah tiap tahunnya. Pada tahun 2014 jumlah penderita DM tipe 2 di UPT. Puskesmas Dawan II Kabupaten Klungkung mencapai 53,26\%. Pada pengobatan Diabetes Melitus tipe 2 di UPT. Puskesmas Dawan II Kabupaten Klungkung dilakukan terapi dengan pemberian obat antidiabetik oral seperti terapi tunggal golongan sulfonilurea yaitu glibenklamid dan terapi kombinasi golongan sulfonilurea dengan golongan penghambat glukoneogenesis yaitu glibenklamid dengan metformin.

Perbedaan terapi yang diberikan pada pasien sering kali berbeda tergantung pada kondisi pasien. Efektivitas dari perbedaan keberhasilan kedua terapi tersebut belum diketahui dengan jelas. Berdasarkan uraian tersebut perlu dilakukan penelitian tentang perbedaan efektivitas penggunaan obat antidiabetik oral tunggal glibenklamid dengan kombinasi antara glibenklamid dengan metformin pada pasien DM tipe 2 di UPT Puskesmas Dawan II Kabupaten Klungkung.

\section{METODE PENELITIAN}

Rancangan Penelitian. Penelitian ini merupakan jenis penelitian cross sectional. Pengambilan data dilakukan dengan pendekatan prospektif yaitu penelitian dimana kesehatan atau karakteristik dari sampel dipantau secara langsung untuk jangka waktu tertentu.

Subjek Penelitian. Populasi dari penelitian ini adalah pasien DM tipe 2 di UPT. Puskesmas Dawan II Kabupaten Klungkung periode November 2015 yang mendapat terapi antidiabetik oral tunggal glibenklamid dan kombinasi glibenklamid dengan metformin. Sampel yang diambil dari populasi yang memenuhi kriteria penelitian.

\section{Kriteria Inklusi}

Pasien dengan diagnosis DM tipe 2 di UPT. Puskesmas Dawan II Kabupaten Klungkung periode November 2015-Pebruari 2016 yang mendapat terapi antidiabetik oral tunggal glibenklamid dan kombinasi glibenklamid dengan metformin.

\section{Kriteria Eksklusi}

a. Pasien DM tipe 2 yang tidak teratur melakukan terapi

b. Pasien DM tipe 2 yang dirujuk ke rumah sakit

c. Pasien dengan kehamilan

Teknik Sampling. Teknik pengambilan sampel dalam penelitian ini menggunakan metode non probability sampling dengan teknik purposive sampling dimana pemilihan sampel dilakukan atas pertimbangan tertentu oleh peneliti (Saryono, 2011). Penelitian ini mengambil 50 sampel yang terdiri dari 25 sampel dengan terapi tunggal dan 25 sampel dengan kombinasi.

Teknik Pengumpulan Data. Dilakukan pengambilan data dari setiap subjek, data yang diambil diantaranya nama, jenis kelamin, umur, diagnosis, hasil laboratorium gula darah puasa, obat yang diberikan selama perawatan dan dosis terapi yang diberikan selama perawatan. Selanjutnya dilakukan pemantauan dan mengamatan terhadap subjek secara berkala selama periode November 2015-Pebruari 2016.

Analisis Data. Data yang diperoleh selama 3 bulan pemantauan terhadap subjek penelitian akan disajikan dalam bentuk tabel, sehingga didapatkan perbedaan efektivitas penggunaan antidiabetik oral tunggal glibenklamid dengan kombinasi glibenklamid dengan metformin pada pasien DM tipe 2 dengan cara membandingkan rata-rata penurunan kadar gula darah puasa dan dianalisis dengan uji statistik dengan taraf kepercayaan $95 \%$. 


\section{HASIL DAN PEMBAHASAN}

Tabel 1. Karakteristik Subjek Penelitian Berdasarkan Jenis Kelamin

\begin{tabular}{|c|c|c|c|c|c|c|c|}
\hline \multirow{3}{*}{ No } & \multirow{3}{*}{$\begin{array}{c}\text { Jenis } \\
\text { Kelamin }\end{array}$} & \multicolumn{4}{|c|}{ Terapi } & \multirow{3}{*}{$\begin{array}{c}\text { Jumlah } \\
\text { Total }\end{array}$} & \multirow{3}{*}{$\begin{array}{l}\text { Persentase } \\
\text { (\%) Total }\end{array}$} \\
\hline & & \multicolumn{2}{|c|}{ Tunggal } & \multicolumn{2}{|c|}{ Kombinasi } & & \\
\hline & & Jumlah & $\begin{array}{c}\text { Persentase } \\
(\%)\end{array}$ & Jumlah & Persentase $(\%)$ & & \\
\hline 1 & Laki-laki & 11 & 44,00 & 11 & 44,00 & 22 & 44,00 \\
\hline 2 & Perempuan & 14 & 56,00 & 14 & 56,00 & 28 & 56,00 \\
\hline & TOTAL & 25 & 100,00 & 25 & 100,00 & 50 & 100,00 \\
\hline
\end{tabular}

Berdasarkan karakteristik jenis kelamin, perempuan lebih banyak mengalami diabetes melitus tipe 2 yaitu sebesar $56,00 \%$. Perempuan lebih banyak mengalami diabetes melitus tipe 2 karena perempuan memiliki komposisi lemak tubuh lebih tinggi dibandingkan laki-laki sehingga perempuan lebih cepat gemuk dan menyebabkan peningkatan kadar gula (Lestari, 2013). Namun tidak menutup kemungkinan laki-laki juga memiliki resiko tinggi terkena diabetes melitus apabila pola hidup yang tidak sehat, karena jenis kelamin sebenarnya bukan salah satu faktor risiko diabetes melitus (ADA, 2012).

Tabel 2. Karakteristik Subjek Penelitian Berdasarkan Umur

\begin{tabular}{|c|c|c|c|c|c|c|c|}
\hline \multirow{2}{*}{ No } & \multirow{2}{*}{$\begin{array}{c}\text { Umur } \\
(\mathbf{T h})\end{array}$} & \multicolumn{2}{|c|}{ Tunggal } & \multicolumn{2}{|c|}{ Kombinasi } & \multirow{2}{*}{$\begin{array}{c}\text { Jumlah } \\
\text { Total }\end{array}$} & $\begin{array}{c}\text { Persentase } \\
\text { Total }\end{array}$ \\
\cline { 3 - 7 } & & Jumlah & $\begin{array}{c}\text { Persentase } \\
(\%)\end{array}$ & Jumlah & $\begin{array}{c}\text { Persentase } \\
(\boldsymbol{\%})\end{array}$ & & 2 \\
\hline 1 & $26-35$ & 0 & 0 & 2 & 8,00 & 2 & 4,00 \\
\hline 2 & $36-45$ & 3 & 12,00 & 2 & 8,00 & 5 & 10,00 \\
\hline 3 & $46-55$ & 5 & 20,00 & 7 & 28,00 & 12 & 24,00 \\
\hline 4 & $56-65$ & 11 & 44,00 & 10 & 40,00 & 21 & 42,00 \\
\hline 5 & $>65$ & 6 & 24,00 & 4 & 16,00 & 10 & 20,00 \\
\hline \multicolumn{2}{|c|}{ TOTAL } & $\mathbf{2 5}$ & $\mathbf{1 0 0 , 0 0}$ & $\mathbf{2 5}$ & $\mathbf{1 0 0 , 0 0}$ & $\mathbf{5 0}$ & $\mathbf{1 0 0 , 0 0}$ \\
\hline
\end{tabular}

Berdasarkan karakteristik umur, pasien paling banyak mengalami DM tipe 2 adalah pasien dengan umur antara 56-65 tahun sebesar 42,00\%. Hasil penelitian ini sama dengan penelitian yang dilakukan oleh American Diabetes Association (2010). Banyaknya penderita DM tipe 2 pada umur diatas 50 tahun karena pada seseorang yang berusia lebih dari 50 tahun dengan pengaturan diet glukosa yang rendah akan mengalami penyusutan sel-sel beta pankreas.

Sel beta pankreas yang tersisa pada umumnya masih aktif, tetapi sekresi insulinnya semakin berkurang. Pada usia ini umumnya manusia mengalami penurunan fungsi fisiologis dengan cepat, sehingga terjadi defisiensi sekresi insulin karena gangguan pada sel beta pankreas dan resistensi insulin (Khotimah K, 2013).

Tabel 3. Karakteristik Subjek Penelitian Berdasarkan Diagnosa Penyakit

\begin{tabular}{|c|c|c|c|c|c|c|c|}
\hline \multirow{3}{*}{ No } & \multirow{3}{*}{ Diagnosa } & \multicolumn{4}{|c|}{ Terapi } & \multirow{3}{*}{$\underset{\text { Total }}{\text { Jumlah }}$} & \multirow{3}{*}{$\begin{array}{l}\text { Persentase } \\
(\%) \text { Total }\end{array}$} \\
\hline & & \multicolumn{2}{|r|}{ Tunggal } & \multicolumn{2}{|c|}{ Kombinasi } & & \\
\hline & & Jumlah & Persentase (\%) & Jumlah & Persentase (\%) & & \\
\hline 1 & DM tipe 2 tanpa komplikasi & 16 & 64,00 & 11 & 44,00 & 27 & 54,00 \\
\hline 2 & $\begin{array}{l}\text { DM tipe } 2 \text { dengan } \\
\text { komplikasi }\end{array}$ & 9 & 36,00 & 14 & 56,00 & 23 & 46,00 \\
\hline & TOTAL & 25 & 100,00 & 25 & 100,00 & 50 & 100,00 \\
\hline
\end{tabular}

Berdasarkan karakteristik diagnosa penyakit terlihat bahwa pasien DM tipe 2 tanpa komplikasi 
hidup, terutama konsumsi makanan yang tidak sehat serta kurangnya aktivitas fisik (Maydani, 2011). Risiko terjadinya komplikasi pada pasien DM tipe 2 dikaitkan dengan lamanya menderita DM tipe 2 dan kadar HbA1C > 7,0\% (ADA, 2016).
Faktor utama pencetus komplikasi pada pasien DM tipe 2 adalah pengaruh kualitas hidup pasien dan kemungkinan terjadinya penyakit komplikasi (Rizkifani S dkk., 2014).

Tabel 4. Karakteristik Subjek Penelitian Berdasarkan Komplikasi

\begin{tabular}{|c|l|c|c|c|c|c|c|}
\hline \multirow{2}{*}{ No } & \multirow{2}{*}{ Komplikasi } & \multicolumn{4}{|c|}{ Terapi } & \multirow{2}{*}{$\begin{array}{c}\text { Jumlah } \\
\text { Total }\end{array}$} & $\begin{array}{c}\text { Persentase } \\
(\%) \text { Total }\end{array}$ \\
\cline { 3 - 6 } & Jumlah & $\begin{array}{c}\text { Persentase } \\
(\%)\end{array}$ & Jumlah & $\begin{array}{c}\text { Persentase } \\
(\%)\end{array}$ & 14 & 53,80 \\
\hline 1 & $\begin{array}{l}\text { DM tipe 2+ } \\
\text { Neuropati }\end{array}$ & 6 & 66,67 & 8 & 57,15 & 12 & 46,20 \\
\hline 2 & $\begin{array}{l}\text { DM tipe 2+ } \\
\text { Hipertensi }\end{array}$ & 3 & 33,33 & 6 & 42,85 & 12 \\
\hline \multicolumn{2}{|c|}{ TOTAL } & $\mathbf{9}$ & $\mathbf{1 0 0 , 0 0}$ & $\mathbf{1 4}$ & $\mathbf{1 0 0 , 0 0}$ & $\mathbf{2 6}$ & $\mathbf{1 0 0 , 0 0}$ \\
\hline
\end{tabular}

Berdasarkan hasil penelitian, penyakit komplikasi neuropati paling banyak ditemukan yaitu sebesar $53,80 \%$. Neuropati merupakan kerusakan saraf yang terjadi karena melemahnya dan merusaknya dinding pembuluh darah kapiler yang memberi makan ke saraf (PERKENI, 2011). Proses terjadinya neuropati biasanya progresif di mana terjadi degenerasi serabut-serabut saraf dengan gejala-gejala nyeri atau bahkan kesemutan, yang terserang biasanya adalah serabut saraf tungkai atau lengan (Hikmat, 2010). Komplikasi lain yang terjadi yaitu hipertensi, sebanyak 46,20\%. Berdasarkan penelitian Hongdiyanto
(2013) dalam penelitian Supriati (2014) menyatakan bahwa hipertensi disebabkan karena kadar gula darah yang terlalu tinggi dan dapat merusak organ dan jaringan pembuluh darah serta dapat terbentuknya aterosklerosis, hal tersebut menyebabkan arteri menyempit dan sulit mengembang sehingga memicu timbulnya hipertensi. Modifikasi gaya hidup dapat menurunkan risiko komplikasi hipertensi pada penyadang diabetes melitus tipe 2 (PERKENI, 2011).

\section{Tabel 5. Karakteristik Subjek Penelitian Berdasarkan Terapi Pengobatan}

\begin{tabular}{|c|l|c|c|}
\hline No & \multicolumn{1}{|c|}{ Terapi } & Jumlah & Persentase (\%) \\
\hline 1 & Terapi Tunggal Glibenklamid & 25 & 50,00 \\
\hline 2 & $\begin{array}{l}\text { Terapi Kombinasi Glibenklamid }+ \\
\text { Metformin }\end{array}$ & 25 & 50,00 \\
\hline \multicolumn{2}{|c|}{ TOTAL } & $\mathbf{5 0}$ & $\mathbf{1 0 0}$ \\
\hline
\end{tabular}

Kombinasi antara glibenklamid dengan metformin bekerja saling sinergis yaitu glibenklamid berfungsi meningkatkan sekresi insulin dan efektif jika pemakaiannya 15-30 menit sebelum makan untuk menghindari efek hipoglikemia dan metformin menurunkan produksi glukosa hati dan meningkatkan glukosa dijaringan parifer (PERKENI, 2011). Pada terapi kombinasi kemungkinan efektivitas pengobatan tidak tercapai karena dosis pemberian yang kurang tepat. Glibenklamid memiliki efek hipoglikemia selama 12-24 jam sementara metformin memiliki lama kerja 6-8 jam (PERKENI, 2011). Interval waktu penggunaan obat merupakan hal yang penting dalam penggunaan suatu obat sebab dapat mempengaruhi lama efektivitas obat tersebut. Interval penggunaan obat yang tidak sesuai akan menyebabkan frekuensi penggunaan obat yang tidak sesuai dan menyebabkan kegagalan terapi (Shargel, 2004). Pemantauan yang dilakukan dalam melihat perbedaan efektivitas dari kedua terapi dengan melihat kadar gula darah puasa dan tidak dilakukan pemeriksaan kadar gula darah sewaktu dan 2 jam post 
prandial. Untuk mengetahui apakah sasaran terapi telah tercapai dan menyesuaikan dosis obat bila sasaran terapi belum tercapai maka ke tiga pemeriksaan tersebut perlu dilakukan secara berkala sesuai dengan kebutuhan.

Tabel 6. Uji Normalitas dengan NPar Tests

\section{One-Sample Kolmogorov-Smirnov Ti}

\begin{tabular}{|ll|r|}
\hline & & \multicolumn{1}{|c|}{ Unstandardized Residual } \\
\hline Normal Parametersa & & 50 \\
& Mean & .0000000 \\
& Std. Deviation & 13.01353305 \\
Most Extreme Differences & Absolute & .223 \\
& Positive & .223 \\
& Negative & .090 \\
Kolmogorov-Smirnov Z & & 1.575 \\
Asymp. Sig. (2-tailed) & &. $\mathbf{0 1 4}$ \\
\hline
\end{tabular}

a. Test distribution is Normal.

\section{Mann-Whitney Test}

\begin{tabular}{|ll|r|r|r|}
\hline \multicolumn{1}{|c|}{ Ranks } \\
\hline Penurunan GDP & Pasien & Mean Rank & Sum of Ranks \\
& Kombinasi & 25 & 22.24 & 556.00 \\
& Total & 25 & 28.76 & 719.00 \\
& & & \\
& 50 & & \\
\hline
\end{tabular}

Test Statistics ${ }^{a}$

\begin{tabular}{|l|r|}
\hline & Penurunan GDP \\
\hline Mann-Whitney U & 231.000 \\
Wilcoxon W & 556.000 \\
$Z$ & -1.582 \\
Asymp. Sig. (2-tailed) & .114 \\
\hline
\end{tabular}

a. Grouping Variable: Pasien

Dari uji normalitas, diketahui data tidak terdistribusi normal $(p=0,014)$. Karena data tidak terdistribusi normal dilakukan uji statistik non parametrik Mann Whitney dengan signifikansi 95\%. Berdasarkan uji statistik Mann Whitney tidak terdapat perbedaan efektivitas penggunaan obat antidiabetik oral tunggal dan kombinasi pada pasien DM tipe 2 di UPT. Puskesmas Dawan II Kabupaten Klungkung periode November 2015Pebruari 2016 yang signifikan $(\mathrm{p}=0.114)$. Hal ini dapat disebabkan karena pengobatan secara farmakologi pada penderita diabetes melitus tidak bisa mencapai sasaran apabila tidak diimbangi dengan pengaturan pola hidup (PERKENI, 2011).
Dari hasil pengamatan secara prospektif melalui wawancara, kurangnya kesadaran dari penderita dalam menjaga pola makan dan kurangnya aktivitas fisik yang mereka lakukan juga merupakan faktor yang dapat memicu kurang efektifnya kerja obat dalam tubuh. Selain itu beberapa penderita sering mengalami stres dan susah tidur. Dalam keadaan stres terjadi perangsangan syaraf simpatoadrenal dan hormon epinefrin sehingga dapat mengakibatkan kadar glukosa darah meningkat (Depkes. RI, 2005). 


\section{SIMPULAN}

Tidak terdapat perbedaan efektivitas pada pengukuran gula darah puasa penggunaan obat antidiabetik oral tunggal glibenklamid dan kombinasi glibenklamid dengan metformin pada pasien DM tipe 2 di UPT. Puskesmas Dawan II Kabupaten Klungkung periode November 2015Pebruari $2016(\mathrm{p}=0.114)$.

\section{DAFTAR PUSTAKA}

American Diabetes Association. 2010, "Standards of Medical Care in Diabetes 2010", America, ADA

Arifin, L.A. 2011, Panduan Terapi Diabetes Melitus Tipe 2 Terkini, Bandung, Fakultas Kedokteran UNPAD/RSUP dr. Hasan Sadikin.

Bina Kefarmasian. 2005, "Pharmaceutical Care Untuk Penyakit Diabetes Melitus",
Direktorat Bina Farmasi Komunitas dan Klinik, Jakarta, Departemen Kesehatan RI.

Departemen Kesehatan R.I. 2007, "Pedoman Pengobatan Dasar Di Puskesmas", Jakarta, Departemen Kesehatan RI.

Notoatmodjo, S. 2010, Metodelogi Penelitian Kesehatan, Rineka Cipta, Jakarta. Indonesia.

Perkumpulan Endokrinologi Indonesia, 2011. Konsensus Pengelolaan dan Pencegahan Diabetes Melitus Tipe 2 di Indonesia. Jakarta, PERKENI.

Saryono. 2011, Metodologi Penelitian Kesehatan, Mitra Cendikia Press, Jogjakarta. Indonesia.

Tjay, T. H. dan K. Rahardja. 2007. Obat-obat Penting: Khasiat, Penggunaan, dan EfekEfek Sampingnya Edisi IV, PT. Elex Media, Jakarta. 